\title{
Influence of increasing doses of a yeast hydrolyzate obtained from sugarcane processing on in vitro rumen fermentation of two different diets and bacterial diversity in batch cultures and Rusitec fermenters
}

\author{
A. Díaz , M.J. Ranilla , C. Saro , M.L. Tejido , M. Pérez-Quintana , M.D. Carro
}

\begin{abstract}
A B S T R A C T
Live yeast cultures and yeast hydrolyzates can be used as rumen fermentation modifiers, but their effects and mode of action are different. Whereas the effects of live yeast cultures on rumen fermentation are well documented, yeast hydrolyzates have received much less attention. The influence of a yeast hydrolyzate from Saccharomyces cerevisiae, obtained after ethanol production from sugarcane (YHS), on in vitro rumen fementation was investigated using both batch cultures and Rusitec fermenters inoculated with ruminal fluid from sheep. Batch cultures ( $300 \mathrm{mg} d r y$ matter (DM)) with two mixed diets (AHC, 0.5:0.5 alfalfa hayconcentrate; BSC, 0.15:0.85 barley straw:concentrate) as substrate were supplemented with increasing doses of YHS $(0,3.3,6.7$, 10.0 and $13.3 \mathrm{ml} / \mathrm{l}$ ) and incubated for $16.5 \mathrm{~h}$ at $39^{\circ} \mathrm{C}$. Supplementation of increasing amounts of YHS to AHC-cultures increased $(P<0.05$ ) linearly total volatile fatty acid (VFA) production and butyrate molar proportion, and decreased $(P<0.001)$ acetate proportion and acetate:propionate ratio. In contrast, only subtle effects of $\mathrm{YHS}$ on $\mathrm{NH}_{3}-\mathrm{N}$ concentrations and molar proportions of isovalerate and caproate were observed for the BSC diet. Longer-term effects of YHS supplementation on rumen fermentation of AHC diet were investigated using four Rusitec fermenters in a cross-over experimental design with two 14-day incubation periods. Fermenters were given daily $30 \mathrm{~g}$ of diet DM, and in each period half of them were supplemented daily with $5 \mathrm{ml}$ of YHS $(10.0 \mathrm{ml} / \mathrm{l})$ Supplementing with YHS did not affect $(P>0.05)$ total VFA production, lactate concentrations, DM and aNDFom disappearance or enzymatic activities (amylase, xylanase and carboxymethylcellulase). Compared with the unsupplemented fermenters, YHS treatment increased $(P<0.001) \mathrm{NH}_{3}-\mathrm{N}$ concentrations and molar proportions of propionate and butyrate at the expense of acetate, and decreased $(P<0.001)$ acetatepropionate ratio. In addition, YHS supplementation tended $(P<0.07)$ to reduce $\mathrm{CH}_{4} /$ total VFA ratio and to increase microbial growth in the liquid phase of the fermenters. The automated ribosomal intergenic spacer analysis (ARISA) of samples taken on days 3,8 and 14 of incubation from solid and liquid content of fermenters revealed that YHS supplementation increased $(P<0.02)$ bacterial
\end{abstract}

Abbreviations: ADFom, acid detergent fiber expressed exclusive of residual ash; AFOM, apparently fermented OM; aNDFom, neutral detergent fiber with heat-stable amylase and expressed exclusive of residual ash: ARISA, automated ribosomal intergenic spacer analysis; $C P$, crude protein: $B S C, 15: 85$ barley straw:concentrate; $A H C$. 50:50 alfalfa hay:concentrate: OM. organic matter: VPA. volatile fatty acids: VH, yeast hydrolyzate; YHS. yeast hydrolyzate obtained from sugarcane processing 
diversity in the liquid phase and tended to increase $(P<0.08)$ it in the solid phase. The results indicate that YHS at a dose of $10 \mathrm{ml} / 1$ may be a useful dietary additive for ruminants, because it promoted a shift in fermentation toward propionate production, reduced the $\mathrm{CH}_{4}$ /total VFA ratio and increased microbial growth with a 50:50 alfalfa hay:concentrate diet.

\section{Introduction}

The identification of substances that modify rumen fermentation to increase its efficiency and decrease the polluting emissions to the environment is a key objective of ruminant nutrition research. Live yeast cultures from Saccharomyces cerevisiae have been shown to modify ruminal fermentation parameters and to have beneficial effects on ruminant performance, but such effects can be influenced by both the yeast culture and the diet fed to animals, among other factors (Carro et al., 1992; Chaucheyras-Durand et al., 2012). Most of the studies on yeast as feed additives have been conducted with live yeast cultures, and the potential of yeast hydrolyzates $(\mathrm{YH})$ as ruminal fermentation modifiers has received much less attention, despite that the effects and mode of action of both additives are completely different. Rossi et al. (2004) reported that the peptidic fractions of $S$. cerevisiae stimulated the growth of Megasphaera elsdenii, the major lactate utilizer in the rumen, and Meissner et al. (2014) observed that a S. cerevisiae YH increased the growth of Megasphaera elsdenii and enhanced the in vitro ruminal fermentation of a high-fermentable substrate. More recently, Kettunen et al. (2016) and Oeztuerk et al. (2016) have reported the efficacy of a patented S. cerevisiae YH product to stimulate the in vitro fermentation of different diets in batch cultures and Rusitec fermenters, respectively.

$S$. cerevisiae is also the most commonly used microorganism to ferment sugarcane juice and molasses for bioethanol production (Laluce et al., 2016), and the residue generated in this process (yeast cream) has been reported to contain about 60-70\% of yeast cells (Pérez et al., 2000; Laluce et al., 2016). The yeast cream is produced in large amounts and has a high pollution potential, but it also contains nutrients and could be used in animal nutrition. The yeast cream can be enzymatically hydrolysed, and the obtained hydrolyzate (YHS) has shown prebiotic effects in broilers (Pérez et al., 2005), but its potential as feed additive in ruminants has not yet been fully analysed. To our best knowledge only Díaz et al. (2009) have tested the effects of YHS and its fractions obtained by centrifugation (supernatant, gross pellet and washed pellet) on in vitro fermentation of Pennisetum purpureum cv. CT-115, and observed that all of them stimulated the in vitro rumen fermentation. However, the influence of this YHS on ruminal fermentation of mixed diets, representative of those used in practical feeding of ruminants, has not yet been tested. Our hypothesis was that the YHS could be effective in modifying rumen fermentation by stimulating the growth of ruminal microbes. The first objective of this study was to test the short-term effects of increasing doses of YHS on in vitro ruminal fermentation of two different mixed diets in batch cultures inoculated with ruminal fluid from sheep fed the same diets used as substrates. The second objective was to determine the long-term effects of YHS on in vitro ruminal fermentation, microbial growth and bacterial diversity in Rusitec fermenters. Diets were formulated to be representative of those fed to dairy and fattening ruminants, and therefore contained different forages.

Table 1

Ingredient composition and chemical analysis of experimental diets fed to donor sheep and used as substrates for the in vitro fermentations in batch cultures.

\begin{tabular}{lll}
\hline Ingredient $(\mathrm{g} / \mathrm{kg}$ of $\mathrm{DM})$ & Diet & \\
\cline { 2 - 3 } & $\mathrm{AHC}$ & BSC \\
\hline Alfalfa hay & 500 & - \\
Barley straw & - & 150 \\
Barley & 199 & 425 \\
Corn & 96.0 & 255 \\
Soybean meal & 71.0 & 150 \\
Lupin & 60.0 & - \\
Oat & 31.5 & - \\
Fullfat soybean & 15.0 & - \\
Calcium carbonate & 6.9 & 6.7 \\
Sugarcane molasses & 5.0 & - \\
NaCl & 3.5 & 3.7 \\
Dicalcium phosphate & 2.1 & - \\
Mineral/vitamin premix & 10.0 & 10.0 \\
Chemical analyses (g/kg of DM) & & \\
Organic matter & 935 & 942 \\
Crude protein & 186 & 150 \\
aNDFom & 394 & 357 \\
ADFom & 179 & 126 \\
\hline
\end{tabular}

Declared composition ( $\mathrm{g} / \mathrm{kg}$ mineral/vitamin premix): Vitamin A, 600,000 IU; Vitamin D3, $120,000 \mathrm{IU}$; Vitamin E, $1 \mathrm{~g}$; Vitamin B1, $33 \mathrm{mg}$; Niacine, $1.5 \mathrm{~g} ; \mathrm{S}, 5 \mathrm{~g} ; \mathrm{IK}, 300 \mathrm{mg} ; \mathrm{SO}_{4} \mathrm{Fe}, 1 \mathrm{~g} ; \mathrm{ZnO}$, $4 \mathrm{~g} ; \mathrm{MnO}, 2 \mathrm{~g} ; \mathrm{CoSO}_{4}, 60 \mathrm{mg} ; \mathrm{Na}_{2} \mathrm{SeO}_{3}, 30 \mathrm{mg}$; Ethoxyquin, $30 \mathrm{mg}$. 


\section{Materials and methods}

\subsection{Animals and diets}

Six rumen-cannulated Merino sheep were used as ruminal fluid donors for the in vitro incubations and Rusitec fermenters. Three sheep were fed a 50:50 alfalfa hay:concentrate diet (AHC) and the other three received a 15:85 barley straw:concentrate diet (BSC). Diets were representative of those fed to dairy and fattening ruminants, respectively. The diets were fed at a fixed rate of $42 \mathrm{~g}$ of dry matter (DM) per $\mathrm{kg}$ of body weigh ${ }^{0.75}$ distributed in two equal meals at 09:00 and 18:00 h for two weeks before starting the in vitro incubations in batch cultures. Ingredient and chemical composition of the diets are shown in Table 1. Samples of the forages and concentrates fed to sheep were ground through a $1 \mathrm{~mm}$ screen and mixed in the corresponding proportion to be used as substrates for in vitro fermentations. Sheep were cared and handled by trained personnel in accordance with the Spanish guidelines for experimental animal protection (Royal Decree 53/2013 of February 1st on the protection of animals used for experimentation or other scientific purposes). The experimental protocols were approved by the León University Institutional Animal Care and Use Committee (Project AIB2010NZ-00190).

\subsection{Yeast hydrolyzate (YHS), substrates, and in vitro fermentations in batch cultures}

The YHS was obtained by enzymatic hydrolysis of the yeast cream resulting from bioethanol production from sugarcane juice and molasses using S. cerevisiae at a sugarcane processing plant (Empresa de Producciones Diversificadas José A. Echeverría, Cárdenas, Matanzas, Cuba). The enzymatic hydrolysis was produced by Bacillus subtilis $\mathrm{E}-44$ at $45{ }^{\circ} \mathrm{C}$ and $\mathrm{pH}=6.0$, as described in detail by Pérez (2000). The YHS was a brown fluid that contained $0.21 \mathrm{~g}$ DM per $\mathrm{g}$ fresh matter. One ml of YHS supplied $8.3 \mathrm{mg}$ of nitrogen, $314 \mu \mathrm{mol}$ of total VFA $(158,52.2,72.9,0.34,1.35,11.9$ and $17.9 \mu \mathrm{mol}$ of acetate, propionate, butyrate, isobutyrate, isovalerate and caproate, respectively) and $291 \mu \mathrm{g}$ of lactate. According to Pérez (2000), the YHS is stable up to six months regardless of storage temperature, and it was stored at $4{ }^{\circ} \mathrm{C}$ during our study.

Díaz et al. (2011) compared the effects of whole YHS and its fractions obtained by centrifugation (supernatant, gross pellet and washed pellet) on in vitro fermentation of Pennisetum purpureum cv. CT-115, and concluded that whole YHS was more effective than any isolated fraction; therefore, the whole YHS was used in this study. Four YHS concentrations were selected from the results of Díaz et al. (2011): 0 (control: CON), 100 (YHS1), 200 (YHS2), 300 (YHS3) and $400 \mu$ (YHS4) per culture. The doses were equally increased, and were equivalent to $0,3.33,6.7,10.0$ and $13.3 \mathrm{ml} / \mathrm{l}$, respectively. Samples of each diet (300 mg DM) were weighed into $120 \mathrm{ml}$ serum bottles, and the YHS was applied inside the bottles immediately before incubation. In order to achieve the same final volume in all the cultures, CON, YHS1, YHS2 and YHS3 bottles received 400, 300, 200 and $100 \mu$ l of distilled water, respectively.

Ruminal contents were obtained immediately before the morning feeding from each sheep, pooled by diet (three sheep per diet), and strained through four layers of cheesecloth into pre-warmed thermal flasks with an $\mathrm{O}_{2}$-free headspace. The fluid was mixed with the buffer solution of Goering and Van Soest (1970; no trypticase added; pH 7.42) in a proportion $1: 4$ (vol/vol) at $39{ }^{\circ} \mathrm{C}$ under continuous flushing with $\mathrm{CO}_{2}$. Bottles of each substrate were filled with buffered ruminal fluid ( $30 \mathrm{ml}$ ) from sheep fed the same diet. Bottles were sealed with rubber stoppers and incubated at $39^{\circ} \mathrm{C}$. Samples of ruminal fluid were taken as described below for VFA and $\mathrm{NH}_{3}-\mathrm{N}$ analysis.

After $16.5 \mathrm{~h}$ of incubation (corresponding to a passage rate from the rumen of $0.06 \mathrm{per} \mathrm{h}$ ), gas production was measured using a pressure transducer (Delta Ohm DTP704-2BGI, Herter Instruments SL, Barcelona, Spain) and a plastic syringe, and a gas sample $\left(10 \mathrm{ml}\right.$ ) was stored in an evacuated tube (Terumo Europe N.V., Leuven, Belgium) for analysis of $\mathrm{CH}_{4}$. Bottles were then uncapped, pH was measured immediately (Crison Basic 20 pH-meter, Crisson Instruments, Barcelona. Spain) and bottles were placed in iced water to slow down fermentation. One $\mathrm{ml}$ of content was added to $0.625 \mathrm{ml}$ of deproteinising solution ( $20 \mathrm{~g}$ metaphosphoric acid and $4 \mathrm{~g}$ crotonic acid per L) for VFA determination, $1 \mathrm{ml}$ was added to $1 \mathrm{ml} 0.5 \mathrm{M} \mathrm{HCl}$ for $\mathrm{NH}_{3}-\mathrm{N}$ analysis, and 1 ml was immediately frozen for lactate analysis.

The experiment was repeated in four non-consecutive days to get four replicates per experimental treatment. Each incubation day, two bottles were incubated for each diet (AHC and BSC) and experimental treatment (CON, YHS1, YHS2, YHS3 and YHS4). A total of 20 bottles with substrate (two per diet and treatment) and 4 bottles without substrate (blanks; two per inoculum) were incubated. Blanks were used to correct the gas production values for gas release from endogenous substrates. Values measured in the two bottles incubated for each diet and experimental treatment were averaged before statistical analysis, and therefore there were four values per diet and experimental treatment.

\subsection{Rusitec trial}

\subsubsection{Experimental design and sampling}

Two identical 14-d incubation runs were carried out using four Rusitec fermenters ( $500 \mathrm{ml}$ effective volume) in a cross-over design. The general incubation procedure was as described by Martínez et al. (2009), and in each run two fermenters received one of the experimental treatments: control (CON) and supplemented daily with $5 \mathrm{ml}$ of YHS (YHS). The YHS dose was selected from the results of the batch cultures trial and the supply of YHS started on day 2 of incubation. On the first day of each incubation run, each fermenter was inoculated with $250 \mathrm{ml}$ of strained rumen fluid, $200 \mathrm{ml}$ of artificial saliva, and $80 \mathrm{~g}$ of solid rumen content supplied into a nylon bag. Ruminal contents (liquid and solid) from three sheep fed a 50:50 alfalfa hay:concentrate diet were collected immediately before the morning feeding, mixed, strained through two layers of cheesecloth, and transferred to the corresponding 
fermenters within 30 min of collection. The liquid flow through fermenters was maintained by continuous infusion of artificial saliva (McDougall, 1948) at a rate of $650 \mathrm{ml} / \mathrm{d}$ (dilution rate of $5.42 \% / \mathrm{h}$ ). Each fermenter received daily $30 \mathrm{~g}$ of DM of the AHC diet (15 g of alfalfa hay and $15 \mathrm{~g}$ of concentrate). Alfalfa hay was chopped (about $0.5-\mathrm{cm}$ pieces) and concentrate was ground through a 3-mm sieve. Each day at 10:00 h, forage and concentrate were fed into separate nylon bags ( $100 \mu \mathrm{m}$ pore; $8 \times 15 \mathrm{~cm}$ ), which were incubated for 48 and $24 \mathrm{~h}$, respectively. Three bags (two with forage and one with concentrate) were consistently kept in each fermenter. Dilution rate and solids retention time were chosen to resemble values previously observed in vivo in sheep (Ranilla et al., $1997,1998)$. Liquid effluent was collected daily in flasks containing $20 \mathrm{ml} \mathrm{of} \mathrm{H}_{2} \mathrm{SO}_{4}(20 \%$; vol/vol) to maintain pH below 2 . On day 13 a water solution saturated with $\mathrm{HgCl}_{2}(5 \mathrm{ml})$ was added (replacing the $\mathrm{H}_{2} \mathrm{SO}_{4}$ solution that could cause bacterial lysis) to the effluent containers, which were held in an iced water bath to impede microbial growth.

After $8 \mathrm{~d}$ of adaptation, on days $9,10,11$ and 12 , samples for gas and for VFA, $\mathrm{NH}_{3}-\mathrm{N}$ and lactate determination in the effluents were collected, and diet apparent disappearance was measured following the procedures described by Martínez et al. (2009). In addition, $3 \mathrm{ml}$ of fermenters' fluid were frozen $\left(-80^{\circ} \mathrm{C}\right)$ for determination of amylase, xylanase and carboxymethylcellulase activities. On days 3,8 and 14 of incubation, $3 \mathrm{ml}$ of fluid from each fermenter were taken into a sterile container and immediately frozen at $-80^{\circ} \mathrm{C}$ for DNA extraction. In addition, the two nylon bags (one with forage and one with concentrate) collected from each fermenter were washed twice with $40 \mathrm{ml}$ of fermenter liquid and the washing fluid was returned to the fermenter. Bags were then opened, their contents were transferred to a sterile container, thoroughly mixed and, about $5 \mathrm{~g}$ were frozen at $-80^{\circ} \mathrm{C}$ for DNA extraction.

On day 10 , dose of $5.6 \mathrm{mg}$ of ${ }^{15} \mathrm{~N}\left({ }^{15} \mathrm{NH}_{4} \mathrm{Cl}\right)$ was added to each fermenter to label instantaneously the $\mathrm{NH}_{3}-\mathrm{N}$ pool. Then, a solution of ${ }^{15} \mathrm{NH}_{4} \mathrm{Cl}$ was added daily to the artificial saliva at a rate of $4.0 \mathrm{mg}$ of ${ }^{15} \mathrm{~N}$ per $\mathrm{g}$ of dietary $\mathrm{N}$ for measuring microbial growth. On days 13 and 14, both effluent and the solid digesta were sampled to determine microbial protein synthesis as described by Carro and Miller (1999). Briefly, about $500 \mathrm{ml}$ of effluent were used for liquid-associated bacteria isolation as described by Martínez et al. (2009) and the rest of the effluent was freeze-dried for DM determination and ${ }^{15} \mathrm{~N}$ enrichment analysis. The contents of nylon bags were thoroughly mixed and used for DM determination, ${ }^{15} \mathrm{~N}$ enrichment analysis and isolation of solid-digesta associated bacteria as detailed by Martínez et al. (2009).

\subsubsection{DNA extraction and automated ribosomal intergenic spacer analysis (ARISA)}

DNA was isolated in triplicate from pellets of centrifuged liquid samples $\left(1 \mathrm{ml}, 20,000 \times \mathrm{g}, 5 \mathrm{~min}, 4^{\circ} \mathrm{C}\right)$ and lyophilized solid digesta samples (200 mg DM) after mechanical disruption of microorganisms with a MiniBead-beater ( 3 min; Biospec Products, Bartlesville, OK, USA). The DNA was extracted following the procedure described by Yu and Morrison (2004) with the exception that an additional step involving the treatment of samples with cetyltrimethylammonium bromide (CTAB) was included to remove PCR inhibitors (Saro et al., 2012), and the QIAamp DNA Stool Mini Kit columns (QIAgen, Valencia, CA, USA) were used to purify the DNA. Absorbance ratios (A260:A280) of eluted DNA were measured in a Nanodrop ND-1000 (Nano-Drop Technologies, Wilmington, DE) to assess the purity of DNA.

For ARISA analyses, the internal transcribed spacer of DNA was amplified using universal bacterial primers $16 \mathrm{~S}-1392 \mathrm{~F}$ and $23 \mathrm{~S}$ 125R as described by Saro et al. (2012). Thermocycling and ARISA technique were conducted in a 2720 Thermal Cycler (Applied Biosystem, Foster City, CA, USA) and a MegaBACE 500 (Amersham Biosciences, Little Chalfont, Bucks, United Kingdom), respectively. Peaks were identified by comparison with an internal size standard using the GeneMarker Software v1.80 (SoftGenetics, State College, PA, USA) and the presence/absence of the different peaks was considered to compare the electropherograms profiles by using a similarity matrix. The Shannon's diversity index was calculated to evaluate the diversity of bacterial communities, and dendrograms were constructed using the Pearson coefficient and the unweighted pair-group method using arithmetic averages (UPGMA) options in the MVSP v3.12d software (Kovach Computing Service, Anglesey, Wales, UK).

\subsection{Analytical procedures}

Dry matter (ID 934.01), ash (ID 942.05), N (ID 984.13) and ADFom (ID 973.18) were determined according to the Association of Official Analytical Chemists (1999). Analyses of aNDFom were carried out according to Van Soest et al. (1991) using an ANKOM ${ }^{220}$ Fibre Analyzer unit (ANKOM Technology Corporation, Fairport, NY, USA). Sodium sulphite and heat-stable amylase were used in analysis of aNDFom. Both aNDFom and ADFom were expressed exclusive of residual ash.

Concentrations of VFA, $\mathrm{NH}_{3}-\mathrm{N}$ and total lactate were determined as described by Garcia-Martinez et al. (2005), and $\mathrm{CH}_{4}$ was analysed by gas chromatography following the procedure described by Martínez et al. (2010). Preparation and analysis of samples for ${ }^{15} \mathrm{~N}$ followed the procedures described by Carro and Miller (1999). Amylase, xylanase and carboxymethylcellulase activities in fermenters' content were determined as described by Giraldo et al. (2007) using soluble starch, oat spelt xylan and carboxymethylcellulose as substrates, respectively.

\subsection{Calculations and statistical analyses}

The amounts of VFA produced in each bottle were calculated by subtracting the amount present initially in the incubation medium from that determined at the end of the incubation period. The amount of organic matter apparently fermented (AFOM) in each culture was estimated from VFA production using the equation proposed by Demeyer (1991).

Effects of YHS supplementation and incubated diet in the experiment with batch cultures were assessed by ANOVA as a mixed model using the PROC MIXED of SAS (version 9.4; SAS Inst. Inc., Cary, NC, USA). Five concentrations of YHS (0, 3.33, 6.7, 10.0 and 
$13.3 \mathrm{ml} / \mathrm{l}$ ), diet (AHC and BSC) and the YHS $\times$ diet interaction wete included in the model as a fixed effects, whereas incubation day was considered as a random effect. Orthogonal polynomial contrasts were used to test for linear and quadratic effects of YHS. Significance was declared at $P<0.05$, whereas $P<0.10$ values were considered to be a trend. When a significant effect of YHS dose was detected, treatment means were compared using the Tukey's test ( $P<0.05$ ). Because each diet was only incubated with ruminal fluid from sheep fed the same diet used as substrate in the batch cultures, the effects of the two factors (inoculum and diet used as substrate) are confounded.

Fermentation and bacterial diversity data from Rusitec fermenters were analysed as a mixed model with repeated measures using the MIXED procedure of SAS (SAS Inst. Inc., Cary, NC, USA). The statistical model used included the YHS treatment, incubation run, time and treatment $\times$ time as fixed effects, and fermenter as a tandom effect. Data on microbial growth were analysed independently for each digesta phase as a mixed model which YHS treatment, incubation tun, and YHS treatment $\times$ incubation run as fixed effects, and fermenter as a random effect. Effects were declared significant at $P<0.05$, and $P<0.10$ was considered a trend.

\section{Results}

The two types of inoculum used in this experiment differed in fermentation characteristics (data not shown). The fluid from AHCfed sheep had greater $(\mathrm{P}<0.05) \mathrm{pH}\left(6.68\right.$ vs. 6.13), $\mathrm{NH}_{3}-\mathrm{N}$ concentrations $(132 \mathrm{vs} .115 \mathrm{mg} / \mathrm{l})$, acetate propottions (64.9 vs. $57.8 \mathrm{~mol} / 100 \mathrm{~mol}$ ) and acetate:propionate ratio $(3.71$ vs. 2.70), but lower $(\mathrm{P}<0.05)$ propionate proportion (17.5 vs. $21.4 \mathrm{~mol} /$ $100 \mathrm{~mol}$ ), compared with the BSC-inoculum.

\subsection{Batch cultures fermentations}

Effects of supplementing batch cultures with YHS on tumen fermentation parameters are shown in Tables 2 and 3 . Yeast hydrolyzate $\times$ diet interactions $(P<0.001-0.007)$ were detected for molar proportions of acetate, propionate and caproate and acetate:propionate ratio, and a trend $(P=0.063)$ to interaction was observed for final $\mathrm{pH}$. Increasing levels of YHS linearly augmented total VFA production $(\mathrm{P}=0.031)$, butyrate $(P=0.007)$ and valerate $(P=0.023)$ proportions, and $\mathrm{NH}_{3}-\mathrm{N}$ concentrations $(P=0.040)$ but decreased $(P<0.001)$ acetate proportions and acetatetpropionate ratio. Effects of YHS on total VFA production, proportions of acetate, butyrate, isovalerate, valerate and acetate:propionate were only observed for the AHC diet, whereas those on $\mathrm{NH}_{3}-\mathrm{N}$ concentrations and isovalerate proportions were only detected for the BSC diet. Neither linear nor quadratic effects $(P=0.127-0.855)$ of YHS supplementation were observed for final $\mathrm{pH}$, total lactate concentrations, or production of gas and $\mathrm{CH}_{4}$ for any diet. The amount of AFOM increased $(P=0.029)$ linearly with increasing doses of YHS for AHC diet, but no effect was observed for the BSC diet. The incubated diet affected $(P<0.001-0.026)$ all parameters measured, with the exception of total lactate concentrations $(P=0.740)$.

Table 2

Effects of increasing doses of a yeast hydrolyzate (YHS) on volatile fatry acids (VFA) production after 16 -h in vitro fermentation of two diets by mixed rumen microorganisms. ${ }^{1}$

\begin{tabular}{|c|c|c|c|c|c|c|c|c|c|c|c|}
\hline \multirow[t]{2}{*}{ Jtem } & \multirow[t]{2}{*}{ Diet } & \multicolumn{5}{|c|}{ Treatment } & \multirow[t]{2}{*}{ SEM } & \multicolumn{4}{|l|}{ P value } \\
\hline & & $\mathrm{CON}$ & YHS1 & YHS2 & YHS3 & YHS4 & & $\mathrm{L}^{2}$ & $Q^{2}$ & Diet & YHS $\times$ Diet \\
\hline \multirow[t]{2}{*}{ Total VFA $(\mu \mathrm{mol})$} & $\mathrm{AHC}$ & $2090^{3}$ & $2075^{\mathrm{a}}$ & $2086^{\mathrm{ab}}$ & $2133^{\mathrm{ab}}$ & $2162^{\mathrm{b}}$ & 24.7 & 0.031 & 0.267 & $<0.001$ & 0.407 \\
\hline & BSC & 2239 & 2203 & 2259 & 2230 & 2250 & & & & & \\
\hline \multicolumn{12}{|c|}{ Molar proportion $(\mathrm{mol} / 100 \mathrm{~mol})$ of: } \\
\hline \multirow[t]{2}{*}{ Acetate } & $\mathrm{AHC}$ & $65.8^{b}$ & $64.8^{b}$ & $63.3^{a}$ & $63.4^{a}$ & $63.2^{\mathrm{A}}$ & 0.37 & $<0.001$ & 0.147 & $<0.001$ & 0.007 \\
\hline & BSC & 51.8 & 51.9 & 52.0 & 51.5 & 51.7 & & & & & \\
\hline \multirow[t]{2}{*}{ Propionate } & $\mathrm{AHC}$ & 19.1 & 19.8 & 20.2 & 20.7 & 20.8 & 0.31 & 0.078 & 0.222 & $<0.001$ & 0.002 \\
\hline & BSC & 31.5 & 30.4 & 30.0 & 30.5 & 30.6 & & & & & \\
\hline \multirow[t]{2}{*}{ Buryrate } & $\mathrm{AHC}$ & $10.3^{\mathrm{a}}$ & $10.5^{\mathrm{a}}$ & $11.4^{\mathrm{b}}$ & $11.4^{\mathrm{b}}$ & $11.2^{b}$ & 0.23 & 0.007 & 0.006 & $<0.001$ & 0.161 \\
\hline & $\mathrm{BSC}$ & 14.3 & 14.9 & 14.9 & 14.8 & 14.6 & & & & & \\
\hline \multirow[t]{2}{*}{ lsobutyrate } & $\mathrm{AHC}$ & 1.19 & 1.65 & 1.58 & 1.16 & 1.20 & 0.20 & 0.804 & 0.109 & 0.026 & 0.691 \\
\hline & $\mathrm{BSC}$ & 0.28 & 0.44 & 0.51 & 0.45 & 0.42 & & & & & \\
\hline \multirow[t]{2}{*}{ Isovalerate } & $\mathrm{AHC}$ & 1.33 & 1.36 & 1.40 & 1.34 & 1.36 & 0.03 & 0.075 & 0.024 & $<0.001$ & 0.429 \\
\hline & $\mathrm{BSC}$ & $0.62^{\mathrm{A}}$ & $0.73^{b}$ & $0.77^{\mathrm{b}}$ & $0.76^{b}$ & $0.73^{b}$ & & & & & \\
\hline \multirow[t]{2}{*}{ Valerate } & $\mathrm{AHC}$ & $1.61^{\mathrm{a}}$ & $1.66^{\mathrm{ab}}$ & $1.74^{\mathrm{b}}$ & $1.61^{\mathrm{a}}$ & $1.88^{\mathrm{b}}$ & 0.07 & 0.023 & 0.682 & $<0.001$ & 0.390 \\
\hline & $\mathrm{BSC}$ & 1.35 & 1.39 & 1.48 & 1.51 & 1.45 & & & & & \\
\hline \multirow[t]{2}{*}{ Caproate } & $\mathrm{AHC}$ & $0.66^{\mathrm{t}}$ & $0.27^{\mathrm{a}}$ & $0.41^{\mathrm{b}}$ & $0.44^{\mathrm{b}}$ & $0.46^{\mathrm{b}}$ & 0.03 & $<0.001$ & $<0.001$ & $<0.001$ & $<0.001$ \\
\hline & BSC & $0.23^{\text {n }}$ & $0.30^{\mathrm{nb}}$ & $0.37^{\mathrm{b}}$ & $0.49^{c}$ & $0.50^{c}$ & & & & & \\
\hline \multirow{2}{*}{$\begin{array}{l}\text { Acetate:propionate } \\
(\mathrm{mol} / \mathrm{mol})\end{array}$} & $\mathrm{AHC}$ & $3.48^{c}$ & $3.30^{b}$ & $3.19^{a}$ & $3.13^{a}$ & $3.10^{\mathrm{n}}$ & 0.04 & $<0.001$ & 0.378 & $<0.001$ & $<0.001$ \\
\hline & BSC & 1.66 & 1.71 & 1.73 & 1.69 & 1.69 & & & & & \\
\hline
\end{tabular}

\footnotetext{
$\mathrm{a}, \mathrm{b}, \mathrm{c}$ For each diet and variable, values not sharing a common superscript differ $(P<0.05)$.

10.100 .200 .300 and $400 \mu \mathrm{l}$ of YHS per batch culture $(30 \mathrm{ml})$ were added for CON, YHS1, YHS2. YHS3 and YHS4. respectively (n = 4). AHC and BSC diets were composed of 50:50 alfalfa hay:concentrate and 15:85 barley strawconcentrate, respectively.

${ }^{2} \mathrm{~L}$ : linear effect of YHS dose; Q: quadratic effect of YHS dose.
} 
Table 3

Effects of increasing doses of a yeast hydrolyzate (YHS) on final $\mathrm{pH}$, concentrations of $\mathrm{NH}_{3} \cdot \mathrm{N}_{\text {and }}$ total lactate, production of gas and CH , $\mathrm{CH}_{4} /$ volatile fatry acid (VFA) ratio and apparently fermented organic matter (AFOM) after 16.h in vitro fermentation of two diets by mixed rumen micro.organisms. ${ }^{1}$

\begin{tabular}{|c|c|c|c|c|c|c|c|c|c|c|c|}
\hline \multirow[t]{2}{*}{ ltem } & \multirow[t]{2}{*}{ Diet } & \multicolumn{5}{|c|}{ Treatment } & \multirow[t]{2}{*}{ SEM } & \multicolumn{4}{|c|}{$P$ value } \\
\hline & & $\operatorname{CON}$ & YHS1 & YHS2 & YHS3 & YHS4 & & $\mathrm{L}^{2}$ & $\mathrm{Q}^{2}$ & Diet & YHS $\times$ Diet \\
\hline \multirow[t]{2}{*}{$\mathrm{pH}$} & $\mathrm{AHC}$ & 6.63 & 6.62 & 6.61 & 6.59 & 6.58 & 0.01 & 0.127 & 0.370 & $<0.001$ & 0.063 \\
\hline & BSC & 6.50 & 6.48 & 6.48 & 6.50 & 6.51 & & & & & \\
\hline \multirow[t]{2}{*}{$\mathrm{NH}_{3}-\mathrm{N}(\mathrm{mg} / \mathrm{l})$} & $\mathrm{AHC}$ & 224 & 221 & 213 & 212 & 238 & 12.1 & 0.040 & 0.843 & $<0.001$ & 0.145 \\
\hline & $\mathrm{BSC}$ & $99.7^{\mathrm{a}}$ & $139^{b}$ & $142^{b}$ & $147^{\mathrm{b}}$ & $146^{\mathrm{D}}$ & & & & & \\
\hline \multirow[t]{2}{*}{ Total lactate (mg/l) } & $\mathrm{AHC}$ & 10.5 & 9.71 & 8.55 & 10.1 & 9.26 & 0.64 & 0.542 & 0.217 & 0.740 & 0.808 \\
\hline & $\mathrm{BSC}$ & 9.22 & 9.21 & 8.47 & 9.12 & 9.36 & & & & & \\
\hline \multirow[t]{2}{*}{ Gas ( $\mu \mathrm{mol})$} & $\mathrm{AHC}$ & 3246 & 3243 & 3271 & 3312 & 3301 & 29.9 & 0.202 & 0.641 & $<0.001$ & 0.561 \\
\hline & BSC & 3431 & 3459 & 3456 & 3441 & 3438 & & & & & \\
\hline \multirow[t]{2}{*}{$\mathrm{CH}_{4}(\mu \mathrm{mol})$} & $\mathrm{AHC}$ & 565 & 550 & 551 & 535 & 551 & 15.6 & 0.505 & 0.816 & 0.170 & 0.907 \\
\hline & BSC & 460 & 463 & 475 & 455 & 461 & & & & & \\
\hline $\mathrm{CH}_{4} / \mathrm{VFA}$ & $\mathrm{AHC}$ & 0.270 & 0.266 & 0.265 & 0.251 & 0.255 & 0.0079 & 0.170 & 0.828 & 0.002 & 0.825 \\
\hline$(\mathrm{mol} / \mathrm{mol})$ & $\mathrm{BSC}$ & 0.205 & 0.210 & 0.211 & 0.204 & 0.206 & & & & & \\
\hline \multirow[t]{2}{*}{ AFOM $(m g)^{3}$} & $\mathrm{AHC}$ & $179^{a}$ & $178^{\text {n }}$ & $180^{\mathrm{A}}$ & $185^{\mathrm{b}}$ & $186^{b}$ & 2.34 & 0.029 & 0.459 & $<0.001$ & 0.254 \\
\hline & $\mathrm{BSC}$ & 203 & 200 & 205 & 202 & 203 & & & & & \\
\hline
\end{tabular}

A,b For each diet and variable, values not sharing a common superscript differ $(P<0.05)$.

${ }^{1} 0.100 .200 .300$ and $400 \mu \mathrm{l}$ of YHS per batch culture $(30 \mathrm{ml}$ ) were added for CON, YHS1, YHS2. YHS3 and YHS4. respectively (n = 4). AHC and BSC diets were composed of 50:50 alfalfa hay:concentrate and 15:85 barley straw:concentrate, respectively.

${ }^{2} \mathrm{~L}$ : linear effect of YHS dose; Q: quadratic effect of YHS dose.

${ }^{3}$ Apparently fermented organic matter estimated from volatile fatry acids production according to Demeyer (1991).

Table 4

Effects of a yeast hydrolyzate (YHS) supplementation on fermentation parameters, diet digestibility, enzymatic activity and microbial protein synthesis in Rusitec fermenters fed a 50:50 forage:concentrate diet $(n=4)$.

\begin{tabular}{|c|c|c|c|c|}
\hline \multirow[t]{2}{*}{ ltem } & \multicolumn{2}{|c|}{ Treatment } & \multirow[t]{2}{*}{ SEM } & \multirow[t]{2}{*}{$P=$} \\
\hline & $\operatorname{CON}$ & YHS & & \\
\hline $\mathrm{pH}$ & 6.50 & 6.52 & 0.051 & 0.817 \\
\hline $\mathrm{NH}_{3}(\mathrm{mg} / \mathrm{l})$ & 339 & 405 & 12.3 & $<0.001$ \\
\hline Total VFA $(\mathrm{mmol} / \mathrm{d})$ & 105 & 106 & 3.3 & 0.801 \\
\hline \multicolumn{5}{|l|}{ Molar proportions $(\mathrm{mol} / 100 \mathrm{~mol})$ : } \\
\hline Acetate & 54.5 & 51.1 & 0.48 & $<0.001$ \\
\hline Propionate & 14.9 & 17.7 & 0.28 & $<0.001$ \\
\hline Butyrate & 17.2 & 18.6 & 0.30 & $<0,001$ \\
\hline Isobutyrate & 1.22 & 1.35 & 0.041 & 0.002 \\
\hline Isovalerate & 4.30 & 3.56 & 0.188 & $<0.001$ \\
\hline Valerate & 4.85 & 5.31 & 0.154 & 0.003 \\
\hline Caproate & 3.06 & 2.35 & 0.138 & $<0.001$ \\
\hline Acetate:propionate $(\mathrm{mol} / \mathrm{mol})$ & 3.67 & 2.89 & 0.085 & $<0.001$ \\
\hline $\mathrm{CH}_{4}(\mathrm{mmol} / \mathrm{d})$ & 29.5 & 28.3 & 0.75 & 0.059 \\
\hline $\mathrm{CH}_{4} /$ Total VFA $(\mathrm{mol} / \mathrm{mol})$ & 0.281 & 0.267 & 0.0090 & 0.064 \\
\hline Lactate $(g / L)$ & 6.25 & 6.69 & 0.907 & 0.559 \\
\hline \multicolumn{5}{|l|}{ Enzymatic activity ${ }^{a}$} \\
\hline Amylase & 0.269 & 0.270 & 0.0330 & 0.973 \\
\hline Xylanase & 0.627 & 0.641 & 0.0361 & 0.616 \\
\hline Carboxymethylcellulase & 0.078 & 0.083 & 0.0092 & 0.536 \\
\hline \multicolumn{5}{|l|}{ Diet dissapearance $(\mathrm{g} / \mathrm{g})$} \\
\hline Dry matter & 0.629 & 0.641 & 0.0096 & 0.158 \\
\hline aNDFom & 0.468 & 0.474 & 0.0139 & 0.636 \\
\hline ADFom & 0.282 & 0.293 & 0.0211 & 0.556 \\
\hline \multicolumn{5}{|l|}{ Microbial growth (mg N/d) } \\
\hline Solid phase & 128 & 129 & 7.1 & 0.899 \\
\hline Liquid phase & 110 & 129 & 3.6 & 0.065 \\
\hline Total & 237 & 258 & 6.8 & 0.165 \\
\hline Efficiency of microbial growth ( $\mathrm{mg} \mathrm{N} / \mathrm{g}$ organic matter apparently fermented) & 24.2 & 23.6 & 0.61 & 0.589 \\
\hline
\end{tabular}

amylase and carboxymethylcellulase activities are expressed as nanomoles of glucose released from soluble starch or carboxymethylcellulose by 1 ml of liquid fermenters' content in 1 min at 39 'C and $\mathrm{pH} 6.5$. Xylanase activity is expressed as nanomoles of xylose liberated from oat spelt xylan by 1 ml of liquid fermenters' content in $1 \mathrm{~min}$ at $39^{\circ} \mathrm{C}$ and $\mathrm{pH} 6.5$. 


\subsection{Fermentation in the Rusitec system}

Effects of YHS on fermentation parameters and bacterial diversity in Rusitec fermenters are shown in Tables 4 and 5 , respectively. The addition of YHS did not affect $(P \geq 0.536) \mathrm{pH}$ before feeding, total VFA production, enzymatic activities or diet disappearance, but modified VFA profile. Compared with the control, the addition of YHS increased $(P \leq 0.003)$ the proportion of propionate, butyrate, isobutyrate and valerate, and decreased $(P<0.001)$ acetate, isovalerate and caproate proportions, and tended to decrease $(P=0.059) \mathrm{CH}_{4}$ production. As a consequence of these changes, YHS-supplemented fermenters had lower $(P<0.001)$ acetate:propionate ratios and tended to lower $(P=0.064) \mathrm{CH}_{4} /$ total VFA ratios. Supplementation with YHS did not affect $(P=0.899)$ microbial growth in the solid phase of fermenters, but tended to increase $(P=0.065)$ microbial growth in the liquid digesta. Efficiency of microbial growth was not affected by YHS supplementation.

As shown in Table 5, both the number of peaks and Shannon index values in the ARISA electropherograms of samples from the liquid digesta were greater ( $P=0.002$ and 0.019 , respectively) in the YHS-supplemented fermenters compared with those unsupplemented. A similar trend $(P \leq 0.077)$ was observed in the solid digesta. Bacterial diversity in the liquid digesta increased $(P<0.001$ ) with incubation time for both treatments (control and YHS), and that in the solid digesta also tended $(P \leq 0.061)$ to increase as time progressed. In addition, the similarity index between the solid and liquid digesta was greater $(P=0.036)$ in YHSsupplemented fermenters than in control ones.

The dendrograms in Fig. 1 clearly show changes in the structure of bacterial populations over the incubation period in our study. It is worth to notice that all samples from day 3 clustered together, for both liquid and solid digesta, although no further subclustering according to treatment or incubation run was observed. In contrast, no clear pattern of clustering according to YHS treatment, sampling day or incubation run was observed for samples taken on days 8 and 14. In general, fermenters 1 and 2 were more similar to each other than to the rest of fermenters, and the same was observed for fermenters 3 and 4 .

\section{Discussion}

The study with batch cultures was designed to investigate the effects of increasing doses of YHS on in vitro ruminal fermentation as influenced by the type of diet fed to donor sheep and incubated as substrate. The type of inocula has been identified as one of the most important factors influencing in vitro fermentation, and previous studies have shown the influence of the inoculum on the main fermentative parameters and the bacterial populations developed in batch cultures (Mateos et al., 2015; Vanegas et al., 2017). Therefore, ruminal fluid from sheep fed the same diet as that incubated in the batch cultures were used to inoculate the cultures with a microbiota representative of that existing in the rumen of sheep fed these diets. The observed values for the fermentation parameters in the two inocula were in accordance with those previously reported in sheep fed similar diets (Carro et al., 2000; Ramos et al., 2009), and seem to indicate the existence of different microbial communities in each of them. Overall, YHS supplementation had only slight effects on the fermentation of BSC diet. In contrast, YHS stimulated the fermentation of AHC diet, as indicated by the increased amount of both total VFA and AFOM. The VFA represent the main supply of metabolizable energy for ruminants, and therefore an increase in their production would be nutritionally favorable for the host animal.

In addition, YHS supplementation of AHC-cultures shifted the rumen VFA profile to less acetate and more propionate (only a trend was observed for propionate), indicating that YHS resulted in more efficient rumen fermentation. Differences in the response to a different $\mathrm{YH}$ supplementation to batch cultures containing substrates varying in grass silage to concentrate ratio $(0.75: 0.25-0.25: 0.75)$ have also been reported by Kettunen et al. (2016). These authors observed a maximum increase of microbial cell density $(20 \%)$ with the substrate containing 0.75 grass silage, whereas lower increases (9-12\%) were detected for the substrates containing lower silage proportions. Similarly, Ospi et al. (2012) reported that the effects of inactivated cells of $S$. cerevisiae on in vitro

\section{Table 5}

Effects of a yeast hydrolyzate (YHS) supplementation on the evolution through the incubation period of number of peaks and Shannon index values detected in the automated ribosomal intergenic spacer analysis (ARISA) electropherograms in solid and liquid contents of Rusitec fermenters, and similarity index of ARISA profiles between solid and liquid contents.

\begin{tabular}{|c|c|c|c|c|c|c|c|c|c|}
\hline \multirow[t]{2}{*}{ Sample } & \multirow[t]{2}{*}{ Item } & \multirow[t]{2}{*}{ Treatment } & \multicolumn{3}{|c|}{ Incubation day } & \multirow[t]{2}{*}{ SEM } & \multicolumn{3}{|l|}{$P$-value } \\
\hline & & & 3 & 8 & 14 & & Treatment & Time & Treatment $\times$ time \\
\hline \multirow[t]{4}{*}{ Solid content } & \multirow[t]{2}{*}{ Number of peaks } & $\mathrm{CON}$ & 38.0 & 40.0 & 41.8 & \multirow[t]{2}{*}{1.81} & \multirow[t]{2}{*}{0.056} & \multirow[t]{2}{*}{0.057} & \multirow[t]{2}{*}{0.213} \\
\hline & & YHS & 40.0 & 46.5 & 41.5 & & & & \\
\hline & \multirow[t]{2}{*}{ Shannon index } & $\mathrm{CON}$ & 3.60 & 3.69 & 3.73 & \multirow[t]{2}{*}{0.048} & \multirow[t]{2}{*}{0.077} & \multirow{2}{*}{0.061} & \multirow{2}{*}{0.270} \\
\hline & & YHS & 3.68 & 3.84 & 3.72 & & & & \\
\hline \multirow[t]{4}{*}{ Liquid content } & \multirow[t]{2}{*}{ Number of peaks } & $\mathrm{CON}$ & $36.0^{\mathrm{a}}$ & $44.3^{b}$ & $43.0^{\mathrm{b}}$ & \multirow[t]{2}{*}{0.98} & \multirow[t]{2}{*}{0.002} & \multirow[t]{2}{*}{$<0.001$} & \multirow[t]{2}{*}{0.399} \\
\hline & & YHS & $37.8^{\mathrm{a}}$ & $47.5^{b}$ & $46.8^{\mathrm{b}}$ & & & & \\
\hline & \multirow[t]{2}{*}{ Shannon index } & $\mathrm{CON}$ & $3.58^{a}$ & $3.79^{b}$ & $3.74^{\mathrm{b}}$ & \multirow[t]{2}{*}{0.023} & \multirow[t]{2}{*}{0.019} & \multirow[t]{2}{*}{$<0.001$} & \multirow[t]{2}{*}{0.493} \\
\hline & & YHS & $3.63^{2}$ & $3.86^{\mathrm{b}}$ & $3.84^{\mathrm{b}}$ & & & & \\
\hline \multirow[t]{2}{*}{ Solid-Liquid } & \multirow[t]{2}{*}{ Similarity index, $\%$} & $\mathrm{CON}$ & $64.9^{\mathrm{a}}$ & $78.3^{c}$ & $73.4^{\mathrm{b}}$ & \multirow[t]{2}{*}{1.893} & \multirow[t]{2}{*}{0.036} & \multirow[t]{2}{*}{$<0.001$} & \multirow[t]{2}{*}{0.181} \\
\hline & & YHS & $71.5^{\mathrm{a}}$ & $77.6^{b}$ & $79.2^{\mathrm{b}}$ & & & & \\
\hline
\end{tabular}

\footnotetext{
${ }^{\mathrm{a}, \mathrm{b}}$ Within each row, means without a common superscript differ $(P<0.05)$. Superscripts are only shown when a significant $(P<0.05)$ effect of time was detected.
} 


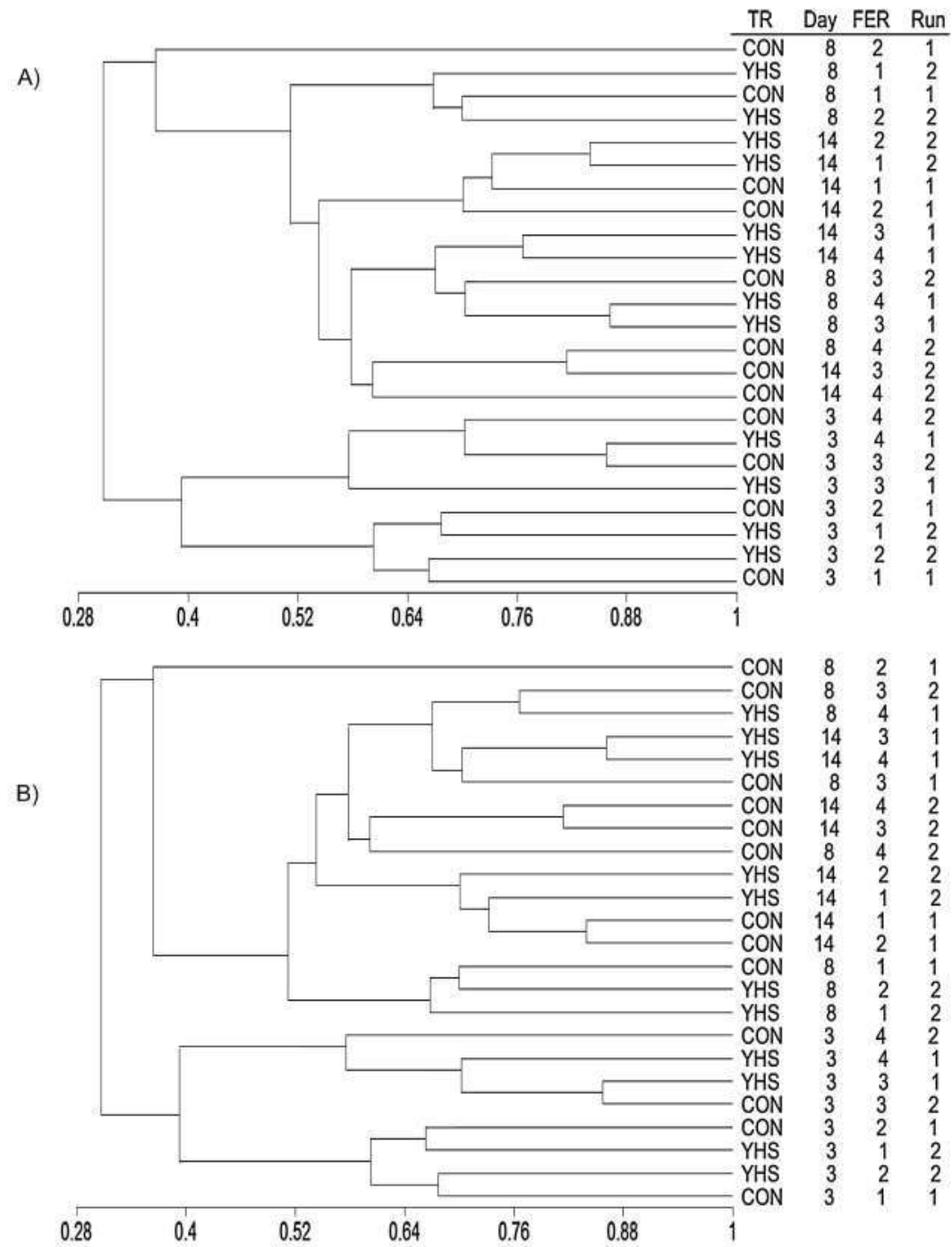

Fig. 1. Dendrograms of ARISA profiles of bacterial communities in solid (A) and liquid (B) phase from Rusitec fermenters on days 3,8 and 14 of incubation and either supplemented with a yeast hydrolyzate (YHS) or not (CON). Numbers 1-4 correspond to individual fermenters (FER). Two identical incubation runs (1, 2) were performed.

ruminal fermentation of substrates with different forage to concentrate ratio were more noticeable with a high-fiber substrate and only subtle effects were detected with a high-concentrate substrate. These results agree with the higher effects of YHS observed in our study for the AHC compared with the BSC diet. Based on these results we decided to investigate the long-term effects of YHS on in vitro fermentation of AHC diet using Rusitec fermenters.

Our results from batch cultures agree with previous studies (Gómez et al., 2005; Martínez et al., 2010) showing that $\mathrm{CH}_{4}$ production in vitro was affected by forage:concentrate ratio in the incubated diet, although YHS did not affect $\mathrm{CH}_{4}$ production and there were no YHS $\mathrm{x}$ diet interactions. Production of $\mathrm{CH}_{4}$ was lower in BSC-cultures than in those containing AHC diet, but it has to be noticed that batch cultures are heavily buffered, and the $\mathrm{pH}$ decrease usually observed in BSC-fed animals diets could not be simulated; therefore, the influence of YHS on rumen $\mathrm{pH}$ could have not been properly tested. Although in vitro studies have some limitations, they constitute a useful tool to test a high number of experimental treatments before performing in vivo trials (Mateos et al., 2015). The higher $\mathrm{NH}_{3}-\mathrm{N}$ concentrations in the AHC-cultures are in accordance with the higher crude protein content of AHC diet compared with BSC-diet (Table 1).

Because no differences among the three highest doses used in the batch cultures (6.7, 10.0 and $13.3 \mathrm{ml} / \mathrm{l})$ were detected in most of the measured parameters, a daily dose of $10.0 \mathrm{ml} / \mathrm{l}$ of YHS was chosen for the Rusitec trial ( $5 \mathrm{ml}$ per day for an effective fermenters' volume of $500 \mathrm{ml}$ ). As observed in the batch cultures, YHS supplementation did not influence fermenters' pH. However, the increase in total VFA production observed in the batch cultures supplemented with YHS was not observed in the fermenters. Although YHS was used at a concentration of $10.0 \mathrm{ml} / 1$ in both YHS3-cultures and Rusitec fermenters, differences in solid/liquid ratio between the two in vitro systems originated marked differences in the YHS dose expressed as $\mathrm{ml} / \mathrm{g}$ diet DM $(1.00$ and $0.17 \mathrm{ml} / \mathrm{g}$ diet DM for YHS3- 
cultures and fermenters, respectively). As a consequence, the amount of DM from YHS supplied to the cultures accounted for $21.0 \%$ of the DM incubated in the YHS3-cultures ( $300 \mathrm{mg}$ DM diet), but only for $3.5 \%$ in the fermenters ( $30 \mathrm{~g}$ DM diet). The increase in VFA production observed in the YHS3-cultures might have been due to the fermentation of the DM added with YHS more than to a stimulation of microbial activity. As discussed by Ospi et al. (2012), yeast do not induce prompt changes in the ruminal microbial population, and thus short-term shifts in fermentation pattern cannot be expected in response to yeast products. However, the observed response could have been mediated by a prebiotic effect of yeast cells, as the YHS used in this study has been reported to contain glucan and mannan oligosaccharide that can be easily fermented by ruminal microbes (Pérez et al., 2016). The increased $\mathrm{NH}_{3}-\mathrm{N}$ concentrations observed in both in vitro systems might also have been due to the microbial degradation of yeast cells because of their high protein content (Oeztuerk, 2009). In fact, daily $\mathrm{NH}_{3}-\mathrm{N}$ outflow was 220 and $263 \mathrm{mg}$ for control and YHS-fermenters, respectively, and the difference between treatments ( $43 \mathrm{mg} \mathrm{NH}-\mathrm{N}$ ) is consistent with the $41.5 \mathrm{mg}$ of $\mathrm{N}$ supplied daily by YHS (1 ml of YHS contained $8.3 \mathrm{mg}$ of $\mathrm{N}$ ). This hypothesis is also supported by the greater isovalerate and valerate proportions in YHS-fermenters compared with control ones, as both VFA are produced mainly from degradation of amino acids by rumen microorganisms. Oeztuerk (2009) observed that the increase in $\mathrm{NH}_{3}-\mathrm{N}$ concentration in Rusitec fermenters produced by a live yeast culture from $S$. cerevisiae was higher than that caused by the same cultures autoclaved, and concluded that the difference between both yeast preparations might have been associated with a stimulation of proteolytic activity of rumen bacteria by live yeast culture. The increased amounts of $\mathrm{NH}_{3}$ $\mathrm{N}$ concentrations in our study seem to be due to the N supply by YHS, and suggest that this YHS would be especially useful to improve ruminal fermentation of nitrogen-deficient diets.

In addition to $\mathrm{N}$, dead yeasts can provide growth factors, such as amino acids, peptides and other compounds essential for some ruminal microbes (Pacheco et al., 1997; Pérez et al., 2016), whose growth can be stimulated. This idea is consistent with the trend to increased microbial growth observed in the liquid phase of the YHS-fermenters compared with control ones. A stimulation of the growth of ruminal bacteria by live (Miller-Webster et al., 2002) and dead (Kettunen et al., 2016) yeast cultures has been shown in some studies, but others have reported no effect (Carro et al., 1992). Moreover, YHS supplementation promoted a greater bacterial diversity in both digesta phases of YHS-fermenters (Table 5). This could indicate that YHS promoted the growth of bacteria that could not be detected in the control-fermenters due to their low abundance. The ARISA is a qualitative technique and does not allow identification of bacterial species, but it is assumed that each peak in the electropherograms reflects the predominant bacterial species or populations present in the samples. However, no clear grouping of samples according YHS treatment was observed in the dendrograms of ARISA profiles, suggesting a high complexity of Rusitec bacteria populations but only subtle differences in their structure between YHS and control fermenters.

In Rusitec fermenters, an adaptation period is required to reach steady-state conditions, and this is reflected both in the fermentation parameters and the structure of bacterial populations that establish in the system. In our experiment, all samples from day 3 clustered together, for both liquid and solid digesta, with no clear pattern of clustering according to sampling day for samples taken on days 8 and 14, indicating the changes in bacterial populations over time in the first days of incubation and the stability reached after adaptation period. Bacterial diversity in the liquid digesta increased from day 3 to days 8 and 14, and a similar trend was observed in the solid digesta for both treatments (control and YHS), suggesting that predominant bacteria in Rusitec fermenters differed from those in the inoculum and that populations developed in the Rusitec are as complex as those in the rumen.

Differences in bacterial populations and/or in their activity in response to YHS supplementation could explain the change in VFA profile observed in the fermenters. Supplementation with YHS shifted VFA profile from acetate to propionate, reducing the acetate:propionate ratio. Similar results have been recently reported by supplementing different YH to batch cultures (Kettunen et al., 2016) and Rusitec fermenters (Oeztuerk et al., 2016). The trend to reduced $\mathrm{CH}_{4}$ production observed in YHS-fermenters in our study is consistent with the increased propionate proportions, as production of propionate serves as a competitive pathway for hydrogen. As a result, $\mathrm{CH}_{4}$ /total VFA tended to be lower in YHS-fermenters, which would indicate a more efficient fermentation.

Finally, the lack of effect of YHS on lactate concentrations in both in vitro experiments is consistent with the idea that dead yeast cells had no effect on lactate production (Miller-Webster et al., 2002; Chaucheyras-Durand et al., 2012). In contrast, live yeasts have been reported to stimulate the growth of rumen lactate-utilizers ( $M$. elsdenii and $S$. ruminantium) by supplying metabolites (i.e. peptides, vitamins, organic acids, ...) that are essential for these bacteria and to reduce lactate concentrations by outcompeting $S$. bovis for the utilization of sugars (Chaucheyras-Durand et al., 2012).

\section{Conclusions}

The effectiveness of the yeast hydrolysate used in this study to modify rumen fermentation was diet-dependent, being more effective with a medium-concentrate than with a high-concentrate diet in short-term in vitro incubations. In long-term in vitro experiments, the yeast hydrolyzate stimulated the rumen fermentation of a 50:50 alfalfa hay:concentrate diet and increased microbial growth. If results are confirmed in vivo, the yeast hydrolysate could be used as a low-cost feed additive.

\section{Acknowledgements}

Funding was provided by the Spanish Ministry of Economy and Competitiveness (Project AGL2008-04707-C02-02 and Acción Integrada AIB2010NZ-00190). A. Díaz gratefully acknowledges the receipt of grants from the Spanish AECID and the Junta de Castilla y León. C. Saro gratefully acknowledges the receipt of scholarship from the Spanish Ministry of Education and Science (AP200603049). 


\section{References}

Association of Official Analytical Chemists. AOAC, 1999. Official Methods of Analysis, 16th ed, 5th revision. AOAC International, Gaithersburg, MD, USA.

Carro, M.D., Miller, E.L., 1999. Effect of supplementing a fibre basal diet with different nitrogen forms on ruminal fermentation and microbial growth in an in vitro semi continuous culture system (RUSITEC). Br. J. Nutr. 2, 149-157.

Carro, M.D., Lebzien, P., Rohr, K., 1992. Influence of yeast culture on the in vitro fermentation (Rusitec) of diets containing variable portions of concentrates. Anim. Feed Sci. Technol. 37, 209-220.

Carro, M.D., Valdés, C., Ranilla, M.J., González, J.S., 2000. Effect of forage to concentrate ratio in the diet on ruminal fermentation and digesta flor kinetics in sheep. Anim. Sci. 70, 127-134.

Chaucheyras-Durand, F., Chevaux, E., Martin, C., Forano, E., 2012. Use of yeast probiotics in ruminants: effects and mechanisms of action on rumen pH, fibre degradation, and microbiota according to the diet. In: Rigobelo, E. (Ed.), Probiotic in Animals. In Tech Editions, Rijeka, Croatia, pp. 119-152.

Díaz, A. Galindo, J., Bocourt, R., Aldana, A.I., Moreira. O., Sarduy, L.. 2009. Efecto de un hidrolizado enzimítico de Saccharomyces cerevisiae y sus diferentes fracciones en la dinímica fermentativa ruminal del pasto estrella (Cynodon nlemfuensis) en condiciones in vitro. Rev. Cub. Cienc Agric. 43, $251-257$.

Díaz, A., Saro, C., Tejido, M.L., Sosa, A., Martínez, M.E., Galindo, J., Carro, M.D., Ranilla, M.J., 2011. Effects of a yeast enzymatic hidrolyzate on in vitro ruminal fermentation. Opt. Mediterranéennes A 99, 181-185.

Demeyer, D.1., 1991. Quantitative aspects of microbial metabolism in the rumen and hindgut. In: Jouany, J.P. (Ed.), Rumen Microbial Metabolism and Ruminant Digestion. INRA Editions, Paris, France, pp. 217-237.

Gómez, J.A., Tejido, M.L., Carro, M.D., 2005. Mixed rumen micro-organisms growth and rumen fermentation of two diets in RUSrTEC fermenters: influence of disodium malate supplementation. Br. J. Ntr. 93, 479-484.

Garcia-Martinez, R., Ranilla, M.J., Tejido, M.L., Carro, M.D., 2005. Effects of disodium fumarate on in vitro rumen microbial growth, methane production and fermentation of diets differing in their forage:concentrate ratio. Br. J. Nutr. 94, 71-77.

Giraldo, L.A., Tejido, M.L., Ranilla, M.J., Carro, M.D., 2007. Effects of exogenous cellulase supplementation on microbial growth and ruminal fermentation of a highforage diet in rusitec fermenters. J. Anim. Sci. 85, 1962-1970.

Goering, M.K., Van Soest, P.J., 1970. Forage fiber analysis (apparatus, reagents, procedures and some applications). Agricultural Handbook, No. 379. Agricultural Research Services, USDA, Washington DC.

Kettunen, K., Vuorenmaa, J., Gaffney, D., Apajalahti, J., 2016. Yeast hydrolysate product enhances ruminal fermentation in vitro. J. Appl. Anim. Nutr. 4, e1-e7. http:// dx.doi.org/10.1017/jan.2015.14.

Laluce, C., Leite, G.R., Zavitoski, B.Z., Zamai, T.T., Ventura, R., 2016. Fermentation of sugarcane juice and molasses for ethanol production. In: O'Hara, I.A., Mundree, S.G. (Eds.), Sugarcane-Based Biofuels and Bioproducts. John Willey \& Sons, Hoboken, New York, pp, 55-86.

Martínez, M.E., Ranilla, M.J., Ramos, S., Tejido, M.L., Carro, M.D., 2009. Effects of dilution rate and retention time of concentrate on efficiency of microbial growth, methane production, and ruminal fermentation in Rusitec fermenters. J. Dairy Sci. 92, 3930-3938.

Martínez, M.E., Ranilla, M.J., Tejido, M.L., Ramos, S., Carro, M.D., 2010. The effect of the diet fed to donor sheep on in vitro methane production and ruminal fermentation of diets of variable composition. Anim. Feed Sci. Technol. 158, 126-135.

Mateos, I., Ranilla, M.J., Saro, C., Carro, M.D., 2015. Comparison of fermentation characteristics and bacterial diversity in the rumen of sheep and batch cuitures of rumen microorganisms. J. Agric. Sci. 153, 1097-1106.

MicDougall, E.1., 1948. Studies on ruminant saliva 1: the composition and output of sheep's saliva. Biochem. J, 43, $99-109$.

Meissner, H.H., Henning, P.H., Leeuw, K.J., Hagg. F.M., Horn, C.H., Kettunen, A., Apajalahti, J.H.A., 2014. Efficacy and mode of action of selected non-ionophore antibiotics and direct-fed microbials in relation to Megasphaera elsdenii NCIMB 41125 during in vitro fermentation of an acidosis-causing substrate. Livest. Sci. $162.115-125$.

Miller-Webster, T., Hoover, W.H., Holt, M., Nocek, J.E., 2002. Influence of yeast culture on ruminal microbial metabolism in continuous culture, J. Dairy Sci. 85, 2009-2014.

Oeztuerk, H., Emre, B., Breves, G., 2016. Effects of hydrolysed yeasts on ruminal fermentation in the rumen simulation technique (Rusitec). Vet. Med. 61, 195-203.

Deztuerk, H., 2009. Effects of live and autoclaved yeast cultures on ruminal fermentation in vitro. J. Anim. Feed Sci. 18 (2009), 142-150.

Ospi, F., Fortina, R., Tassone, S., Bodas, R., López, S., 2012. Effects of inactivated and live cells of Saccharomyces cerevisiae on in vitro ruminal fermentation of diets with different forage:concentrate ratio. J. Agric. Sci, 150, 271-283.

Pérez, M., Piad, R., Bocourt, R., Milian, G., Medina-Medina, E., Savon, L., Sarduy, L., Laurencio, M., 2005. Actividad prebiótica y probiótica de un hidrolizado enzimático de crema de destilería en pollos de cebo (Prebiotic and probiotic activity of an enzymatically bydrolyzate of yeast cream in broilers). Cien. Tecnol. Alim. 5, 42-47.

Pérez, M., Milian, G., Bocourt. R., Alemán, R., 2016. Evaluación in vitro de prebióticos en hidrolizados de levadura (Saccharomyces cerevisiae) preparados por diferentes métodos (In vitro evaluation of prebiotics in hydrolysates of yeast (Saccharomyces cerevisiae) prepared by different methods). Cien. Vida $16,64-75$.

Pérez, M., 2000. Obtención de un hidrolizado de crema de levadura de destilería y evaluación de su actividad probiótica (Obtaining a Yeast Hydrolyzate from Yeast Cream and Evaluation of Its Probiotic Effects). Universidad Agraria de La Habana, La Habana. Cuba PhD Thesis.

Pacheco, M.T., Caballero-Córdoba, G.M., Sgarbieri, V.C., 1997. Composition and nutritive value of yeast biomass and yeast protein concentrates. J. Nutr. Sci. Vitaminol. (Tokyo) 43, 601-612.

Ramos, S., Tejido, M.L., Ranilla, M.J., Martinez, M.E.., Saro, C.. Carro, M.D., 2009. Influence of detachment procedure and diet on recovery of solid-associated bacteria from sheep ruminal digesta and representativeness of bacterial isolates as assessed by automated ribosomal intergenic spacer analysis-polymerase chain reaction. J. Dairy Sci. 11, 5659-5668.

Ranilla, M.J., Carro, M.D., Valdés, C., Giráldez, F.J., Lopez, S., 1997. A comparative study of ruminal activity in Churra and Merino sheep offered alfalfa hay. Anim. Sci. $65,121-128$.

Ranilla, M.J., López, S., Giráldez, F.J., Valdés, C., Carro, M.D., 1998. Comparative digestibility and digesta flow kinetics in two breeds of sheep. Anim. Sci. 66, 389-396.

Rossi, F., Di Luccia, A., Vincenti, D., Cocconcelli, P.S., 2004. Effects of peptidic fractions of Saccharomyces cerevisiae culture on growth and metabolism of the ruminal bacteria Megasphaera elsdenii. Anim. Res. 53, 177-186.

SAS (Statistical Analysis Systems), 2004. SAS Procedures Guide Release 9.1 Edition. SAS Institute Inc, Cary, NC, USA.

Saro, G, Ranilla, M.J., Carro, M.D., 2012. Postprandial changes of fiber-degrading microbes in the rumen of sheep fed diets varying in type of forage as monitored by real time PCR and automated ribosomal intergenic spacer analysis. J. Anim. Sci. 12, 4487-4494.

Van Soest, P.J., Robertson, J.B., Lewis, B.A., 1991. Methods for dietary fiber, neutral detergent fiber, and nonstarch polysaccharides in relation to animal nutrition. J. Dairy Sci. 74, 3583-3597.

Vanegas, J.L., González, J., Alvir, M.R., Carro, M.D., 2017. Influence of malic acid-heat treatment for protecting sunflower protein against ruminal degradation on in vitro methane production: a comparison with the use of malic acid as an additive. Anim. Feed Sci. Technol. $228,123-131$.

Yu, Z., Morrison, M., 2004. Improved extraction of PCR-quality community DNA from digesta and fecal samples. Biotechniques $36,808-812$. 